\title{
The Spirituality of Teresa of Avila and the Latin Manuscript about the Dutch War (folios 3or-49v)
}

\author{
Elisabeth Hense
}

\section{Introduction}

The spirituality of Teresa of Avila permeates Maria Petyt's writings to such an extent that we cannot fully understand her autobiography and letters without knowing Teresa's main works. ${ }^{1}$ Teresa's legacy seems to be the key not only to Maria's Dutch writings but also to the Latin manuscript about the Dutch War (1672-1678).

The intimate relation between the spirituality of the two women manifested in the Latin manuscript about the Dutch War can be demonstrated by focusing on mental prayer, which both women considered the principal form of their spiritual life. ${ }^{2}$ First I will comment on mental prayer in The Interior Castle (or The Mansions) of Teresa of Avila. ${ }^{3}$ Then I will show that Maria Petyt had a natural affinity with mental prayer from her youth onwards, but did not really understand it until she began reading Teresa's works and was progressing on the spiritual path. Next I will identify the levels of mental prayer in the Latin manuscript about the Dutch War, which prove to be the supernatural levels corresponding with the fourth to seventh mansions of The Interior Castle. I will conclude with an evaluation of Maria's visions and experiences relating to the French king and his army in the context of these heightened levels of mental prayer.

The rearrangement of folios 3 or to $49 \mathrm{v}$ of the Latin manuscript about the Dutch War - whether intentionally or accidentally ${ }^{4}$ - joins together those

1 Cf. Deblaere (1962) 145-52. Deblaere writes extensively about the influence of Teresa's life on Maria Petyt. He detected parallels between Teresa's and Maria's Christ-centred mysticism, their experiences of illness and their devotion to St. Joseph. He considers Teresa's concept of visions as recorded in The Interior Castle to have influenced Maria.

2 Deblaere does not mention Teresa's influence on Maria Petyt in respect of mental prayer.

3 The Interior Castle was first translated into Dutch by the Franciscan Willem Spoelberch in 1608 (Brussels and Antwerp). After that year Teresa's works became widespread in Dutch speaking areas.

4 See Giovanni Grosso's contribution to this volume, p. 83-91.

(C) ELISABETH HENSE, 2015 | DOI 10.1163/9789004291874_011

This is an open access chapter distributed under the terms of the Creative Commons AttributionNoncommercial 3.0 Unported (CC-BY-NC 3.0) License. 
parts of the manuscript that relate closely to the supernatural levels of mental prayer described in The Interior Castle (folios 3or-37v), whereas the folios of minor interest concerning these supernatural levels (folios $38 \mathrm{r}-49 \mathrm{v}$ ) can be seen as a second part of the manuscript about the Dutch War.

\section{Mental Prayer in The Interior Castle}

The Interior Castle is divided into seven mansions (also called dwelling places), each representing a certain level of mental prayer that brings the soul step by step closer to God.

The entrance to the castle takes the form of active prayer, characterized by conscious striving to stay in God's presence. ${ }^{5}$ When the soul starts to practise this kind of prayer she also starts realizing her own inner beauty given to her by the grace of God despite her human shortcomings, sins and puniness. Proceeding to the second and third mansions, the soul seeks to advance through meditation on God's works, empathizing with God's love for creation, and through humble daily attention to the divine presence. She now has to persevere in prayer - even in times of mental aridity or temptation, when Satan tries to block her path and dissuade her. The soul's desire to do charitable works is growing and so is her aversion to sinning. By gently acquiring the habit of recollection and remaining in a state of surrender to God the soul finally manages to enter the other mansions.

The fourth to seventh mansions are considered mystical. ${ }^{6}$ From now onwards the soul has to cease her own activity and gradually let God take over. She experiences divine delights flowing directly from God, leaving her peaceful, calm and filled with sweetness. ${ }^{7}$ She comes to know the prayer of quiet, during which she surrenders herself into God's hands. ${ }^{8}$ In the fifth mansion the soul is immersed in the prayer of divine union. ${ }^{9}$ In this kind of prayer, union with God's will is much more important than temporary ecstatic union. ${ }^{10}$ The two kinds of union induce such powerful perceptions that she cannot doubt them. ${ }^{11}$ The comparison with a silkworm developing into a butterfly

\footnotetext{
5 Ch. I. For the English translation, see Kavanaugh \& Rodriguez (1980) 261-452.

6 IV-VII.

7 IV, 2-3.

8 IV, 3. For the controversy about the prayer of quiet in Maria's time, see Esther van de Vate's contribution to this volume, p. 92-118.

$9 \quad$ IV

$10 \mathrm{~V}, 3 \cdot 3$.

$11 \quad \mathrm{~V}, 1.9$.
} 
conveys the transforming power of the prayer of union..$^{2}$ This is where Teresa talks about spiritual betrothal for the first time. ${ }^{13}$ In the sixth mansion the soul spends more and more time with her beloved, but at the same time is exposed to many outside afflictions. ${ }^{14}$ She again undergoes severe temptations and inner struggle and she pines away with fervent desire for God. She understands how to discern his favours (trances, ecstasies, raptures, flights of the spirit, jubilation, visions) from the effects of fantasy and imagination. ${ }^{15}$ The soul achieves full clarity in prayer and spiritual marriage with God in the seventh mansion. ${ }^{16}$ Here God and the soul become absorbed in each other's affairs. They cannot be separated any more - they are indistinguishable, one and the same. ${ }^{17}$

\section{Maria's Natural Affinity with Teresa}

In her autobiography Maria Petyt tells us that she first discovered mental prayer when she was twelve. Mental prayer was easy and delightful for the young girl: she enjoyed spending her time absorbed in God's presence. The sweetness of these experiences sometimes lasted two hours.

Our Beloved Lord then gave me the gift of mental prayer, and as I have come to understand now, more than mental prayer, sometimes even supernatural prayer. I seemed to be drawn into great devotion and exaltation of the spirit, I don't know how or where. Sometimes this lasted two hours. I continued this sort of prayer for such a long time without any effort or labour and as far as I can remember with a sweet and flaming love. ${ }^{18}$

$12 \mathrm{~V}, 2.7$.

$13 \mathrm{~V}, 4.3$.

14 VI, 1.

15 VI, 2-10. For discernment of spirits in Maria's works, see Veronie Meeuwsen's contribution to this volume, p. 240-251.

16 VII.

17 VII, 2.4.

18 We do not know whether Maria took the practice of mental prayer directly from the writings of Teresa or whether it came to her via her spiritual environment. Cf. Merlier (1976) ch. IX = Petyt (1683) vol. 1, 12.: 'Onsen Lieven Heer gaf my van alsdan de gratie van het verstandelijck Ghebedt, ende soo my nu dunckt, meer als verstandelijck Ghebedt, oock somtyts tot het overnatuerlijck Ghebedt, soo dat ick scheen opghetrocken te zijn in een groote aendachtigheyt ende verheventheyt des geests, ick en weet niet, hoe, oft waer, somtyts twee 
In Teresa's and Maria's terminology mental prayer can be natural - this relates to the first mansion of The Interior Castle where the soul is actively acquiring the habit of prayer - and it can be supernatural - this relates to later mansions of The Interior Castle where God pours prayer into the soul while she remains passive. It was the sweetness of this passively received divine gift that the young girl was often allowed to enjoy for lengthy periods.

Maria discovered another taste of this divine gift in her early twenties, shortly after leaving the cloister of the Augustinian nuns. In this period uncertainty about her future troubled her and now she experienced mental prayer as a guiding power that could balance her and orient her towards her intimate life with God despite many outward anxieties. She often sat in a church and gained a sense of security, assistance and support during mental prayer. She clearly understood what should be the goal of her life and wrote a vivid account of it for her spiritual father, ${ }^{19}$ but he did not recognize Maria's inward state. Neither did Maria, for she did not yet understand the writings of Teresa of Avila too well.

In that prayer my Beloved gave me such clear insight into the kind of prayer and inward exercise that I should practise and into the path that he wanted me to take that I wrote a whole page about it. But the content of this insight and instruction was so perfect and utterly pure that I am at this moment not yet able to experience it fully. The Beloved instilled in me the goal to which he called me. But I couldn't understand the content as I understand it now. I shall have to work all the days of my life to properly experience the instructions that my Beloved gave me inwardly on that day. ${ }^{20}$

uren lanck gheduerende. Ick continueerde in dese soorte van Ghebedt soo langhen tydt sonder eenighe moeyte, oft aerbeyt, soo veel, als my ghedenckt met een soete, opvlammende liefde.'

19 A Carmelite father, cousin of a friend of Maria Petyt, whose name we do not know. Cf. Merlier (1976) ch. XXIII-XXIV = Petyt (1683) vol. 1, 31ff.

Het leven van Maria Petyt, ch. XXvI = Petyt (1683) vol. 1, 36. : 'Mijnen Beminden gaf my in dat Ghebedt soo klaer te kennen de maniere van Ghebedt, ende inwendighe oeffeninge, die ick moest houden, ende door wat wegh, dat hy my leyden wilde, dat ick'er wel een heel bladt papier vol van schreef; maer het inhout van dese kennisse ende inlichtinghe was van een soo groote volmaecktheyt,ende uytterste puerheyt, dat ick teghenwoordigh de selve noch niet volkomelijck beleeft en hebbe; den Beminden gaf my in, het eynde, daer hy my toe riep, maer ick en verstondt het inhout niet, ghelijck ick nu dat verstaen, want my dunckt, dat ick mijn leven daghen werckx ghenoegh hebben zal, om die leeringhe volmaecktelijck te beleven, die den Beminden my inwendigh alsdan heeft ghegheven.' 
Although Maria had experienced mental prayer from her twelfth year onwards and she enjoyed the sweetness and strength of that prayer, she did not fully fathom it at the time. She perceived the beneficial effects of mental prayer, but did not really grasp what it was about. She might have formed a better idea some months later, when she mentioned Teresa in her diary for the first time. ${ }^{21}$ Teresa was a shining example to the young woman and Maria wanted to throw herself straight into the spiritual path that Teresa had taken. Maybe now she started to comprehend mental prayer as a powerful means for her spiritual life.

During the years that followed she grew in mental prayer and - as we shall see - might have experienced its fullness in her twilight years, when she was concerned about the French king's war in Holland.

Against the background of her own experiences of mental prayer it is not surprising that Maria felt an intense spiritual kinship with Teresa and that she added Teresa's name to her own when she took vows in the Third Order of the Carmelites: thenceforth she called herself Maria of St. Teresa.

\section{Levels of Mental Prayer in the Latin Manuscript about the Dutch War}

Maria's chronicle of 7 November 1672 speaks about the prayer of quiet that Maria enjoyed when her inner engagement with the French king had been going on for two years.

For some days I was drawn to a profound and intimate quiet in the Beloved as a sleep of love with the passing of all things that are not Him, perceiving nothing in me other than his presence. ${ }^{22}$

She remained for some days in this prayer ${ }^{23}$ held in divine love 'with a noticeable and pleasant darkening of the light and with the radiance of his divinity, a

$21 \quad$ Merlier (1976) ch. XXXVI = Petyt (1683) vol. 1, 49: '(...) my docht, dat in Godt my gheene dinghen onmoghelijck en waeren, ja oock niet moeyelijck, soo dat ick altemet hoorende spreken ofte lesen vande groote heyligheyt van de Heylighe TERESIA, seyde met onnooselheyt, ick hope oock Heyligh te worden, om dieswille dat ick in my soo stercken wille ghevoelde, om my ten uyttersten te laeten kosten, gheen moeyte, oft aerbeyt aensiende, om de deught te beherten, ende te vervolghen; t'saemen oock een hope op Godt, dat sijne gratie my noyt en soude ontbreken, ghelijckse aen de Heylighen noyt ontbroken en heeft.'.

223 3or.

23 Cf. 1 Thess. 5:17: '(...) pray continually'. During this prolonged prayer she remained able to function in all necessary activities, as she said elsewhere (see e.g. 35v). Teresa wrote about the same experience in VII, 1.8 . 
light that brightened and penetrated all the powers of my soul. ${ }^{24}$ During the prayer of quiet Maria did not eliminate her political commitment. On the contrary, she found herself encouraged in her solidarity with the French king: 'Then again the spirit of prayer for the king of France penetrated me (...) A spirit that began to work vividly and powerfully in his assistance and support. ${ }^{25}$

The prayer of quiet belongs to the fourth mansion of The Interior Castle, described by Teresa as follows: 'It is a recollection that (...) seems to me to be supernatural. (...) They say that the soul enters into itself and, at other times, that it rises above itself.' 26

Teresa considered the prayer of quiet to be the beginning of mystical or supernatural prayer. At the threshold to this kind of prayer the soul no longer exerts human effort but surrenders herself totally into God's hands.

When his majesty desires the intellect to stop he occupies it (...) and gives it a light so far above what we can attain that it remains absorbed. Then, without knowing how, the intellect is much better instructed than it was through all the soul's efforts not to make use of it. ${ }^{27}$

This means, as Teresa put it, that the soul no longer needs to construct the 'many aqueducts' 28 to connect with God, who is her spiritual wellspring. In the prayer of quiet the water flows readily from God directly into the soul. ${ }^{29}$ Even if the soul wants to remain active and work, she cannot.

Maria Petyt refers to the divine spring most explicitly in 32r:

This prayer flowed very nobly and vigorously from God, like from his spring water, or origin, and flowed back to God, like to his goal with the same tranquillity, peace and intimacy and without the imagination of any other corporeal thing, without forming words or sentences, distinguishing nothing but God, to whom I looked up and loved with a burning mind and with burning desires of being heard. This burning mind and these fiery desires stood as it were open before God with an effective and burning intercession.

$\begin{array}{ll}24 & \text { 3or. } \\ 25 & \text { 3or. } \\ 26 & \text { IV, 3.1-2. } \\ 27 & \text { IV, 3.6. } \\ 28 & \text { IV, 2.3. } \\ 29 & \text { Cf. IV, 3.8-9. }\end{array}$


In Maria's case, being absorbed in the prayer of quiet while remaining engaged with the French king implies that she saw her political commitment to the French king flowing directly from God into her soul - her soul remaining quiescent, receptive to the divine inspiration.

Some months later ${ }^{30}$ Maria went beyond the prayer of quiet. She now entered what Teresa called the prayer of union. This prayer is typical of the fifth mansion, characterized by Teresa as very deep, sound spiritual sleep.

There is no need here to use any technique to suspend the mind, since all the faculties are asleep in this state - and truly asleep - to the things of the world and to ourselves. As a matter of fact, during the time that the union lasts the soul is left as though without its senses, for it has no power to think even if it wants to. In loving, if it does love, it doesn't understand how or what it is it loves or what it would want. In sum, it is like one who in every respect has died to the world so as to live more completely in God. ${ }^{31}$

During the short period of the prayer of union the devil cannot mislead the soul with corporeal or imaginary visions. ${ }^{32}$ Without seeing anything with either her bodily eyes or the eyes of the soul the person unites with God so intimately that she senses the divine presence simply in a so-called intellectual vision. Following the spiritual tradition, Teresa understood intellectual vision to be a powerful, sure sense of connectedness and oneness with God - a feeling that cannot be doubted. ${ }^{33}$ In The Interior Castle this feeling already occurs in the fifth mansion, although Teresa does not describe the intellectual vision until the sixth mansion.

When Maria immersed herself in the prayer of union her inner engagement with the French king persisted, although her environment was critical of it. But Maria felt serene, because she understood her experiences to arise from the prayer of union:

My human spirit is not doing this in me, but it is the Spirit of God united with my spirit that works in me and through me and with me. This happens at a time of very great quiet and calm, of intimate connection or union of my spirit with the divine, without words, without thoughts, and

\footnotetext{
30 Cf. 31r. The manuscript does not give an exact date.

$31 \quad \mathrm{~V}, 1.4$

$32 \quad \mathrm{~V}, 1.5$

33 VI, 8.2
} 
almost without any imagination of any corporeal thing. This disposition is too noble and too intimate to allow or tolerate any imaginative or physical representation of the image of a thing known or remembered in God, as if intellectual visions or images (as seems to me) are the highest, which are tolerated there, but if I would intermingle myself in it, no matter how much and no matter where, the spirit would immediately and completely evaporate and would be obscured and I would return to my nature. ${ }^{34}$

These words explicitly indicate that there can be no doubt about the divine character of her experiences and that they should be understood as manifestations of the prayer of union. While absorbed in this kind of prayer Maria felt strong divine support for her inner solidarity with the French king and she felt sure that God would grant him victory 'even if appearances might suggest otherwise, as when two or three strong armies of mighty and stalwart soldiers experienced in war were to oppose him. 35

According to Teresa the soul should merge her will with the will of God during this state of union and should rate the conformity to God's will far more highly than the ecstatic feelings caused by this union. ${ }^{36}$ Ecstatic feelings are temporary, while the union of the human and the divine will may last for ever. Thus by focusing on the conformity of her will to the will of God Maria emphasized the stability and reliability of her relationship with God.

To whatever God turns, to that also my soul ought to turn. Whatever God loves, the soul also has to love that, from whatever God turns away, from that also the soul turns away, nor can the soul act in any other way, because God possesses it, moves it, leads it and is united with it, where it is one being, one working, one understanding and one willing with God. ${ }^{37}$

Hence this trustworthy uniformity of God's will and Maria's forms the basis of her prayer for the French king but this does not mean that everything remains delightful. As Teresa indicated in the sixth mansion of The Interior Castle, there might still be a lot of turmoil and doubt even after experiencing the prayer of union. Teresa refers to severe illness which is to be anticipated in this period. From her own experience this seemed a greater trial than all other external tribulations that she suffered.

\begin{tabular}{ll}
\hline 34 & $31 r$. \\
35 & $31 r$. \\
36 & V, 1.12; V, 2.12; V, 4.5. \\
37 & $31 \mathrm{v}$.
\end{tabular}


The Lord is wont also to send it (the soul) the severest illnesses. This is a much greater trial, especially when the pains are acute. For in some way, if these pains are severe, the trial is, it seems to me, the greatest on earth - I mean the greatest exterior trial, however many the other pains. I say 'if the pains are severe', because they then afflict the soul interiorly and exteriorly in such a way that it doesn't know what to do with itself. ${ }^{38}$

Knowing that Maria structured her chronicles according to the higher mansions of The Interior Castle, we are not surprised to find a parallel with this state of trouble and corporeal and inner pain in Maria's diary. In the beginning of July $1673^{39}$ she entered a period of extreme endurance of some sort of acute pain.

After my proposal to make reparation for him and even to suffer infernal penances, the Beloved used me until the 8th of July, according to all appearances, to make reparation for the faults of the king of France. For sure that was something that was allowed to happen to me in some way by an unusual and by me not yet endured torment, which I had to undergo in my soul, and which seemed to me to be an infernal punishment. To me it seemed that under my heart as it were a fire was ignited, through which my heart was tortured and tormented. Besides all of this, there was all that came to me through the senses, through hearing, through vision, touch and taste. Also through imagination or other sensory powers, all these things, that I had rejected seemed to press upon my heart, to torture it in an ineffable manner.

(...). Sometimes because of the violence of the punishments I was as it were outside myself and my intellect was darkened and in fact because of the long lasting duration I suffered like a criminal. For my powers were (strength was) consumed by that very great suffering in spirit and nature. (...). Mostly I remained in a harassing (distressing) state, feeling particularly my natural suffering, which comes back to life and even seems to become more vigorous than ever, especially making me feel as if I was about to contract Cholera. And although by God's grace I will not catch that disease, it still is a heavy cross for me to feel these things so in such a lifelike way. ${ }^{40}$

\footnotetext{
$38 \quad$ VI, 1.6.

39 The year is missing in the manuscript, but is probably 1673 .

$40 \quad 34$ r.
} 
Again following Teresa's understanding of these experiences, Maria interpreted corporeal and spiritual pain as divine punishment for sin - in Maria's case the sins of the French king - and as a purification of the soul - in Maria's case in order to deepen her humility. ${ }^{41}$ Teresa and Maria both mentioned that they faced heavy opposition in that state and that their environment seemed to be enraged with them. ${ }^{42}$ Both talk about a period of reconsidering all earlier spiritual experiences and being boiled down to nothingness. ${ }^{43}$

Finally there is a resumption of loving union with God. Here Teresa spoke about spiritual marriage, a state in which the soul considers God's affairs to be her own and 'that he would take care of what was hers' 44 On 30 December 1673 Maria again reported her experience of being drawn to her bridegroom and dealing with his affairs in this state:

I was turned or drawn inward in that extraordinary and very great union with the Divinity, as I had enjoyed it for one year or another. In this union, suddenly I was somewhat brought down by forces with some perception of myself, not in a rude, but in a very sublime, spiritual and noble way, in the quality of a very tender and loving bride, who is permitted or better who is so by the divine spirit, that she associates with her divine Beloved confidently and familiarly, and speaks about things that concern Him. ${ }^{45}$

In Maria's case the affairs of her beloved concerned the blessing of the French king and the struggle against the heretics, whether Protestants or Jansenists. ${ }^{46}$ In this state it seemed to Maria that her beloved understood her without any words and she understood him:

There the soul does not speak or beg, nor does it pray blandly for forgiveness, nor does it represent anything, nor does it commend something expressly that is far away, but it sees in God as in a mirror those things for which God wants it to pray, just as if God sees in my soul those things for which it begs or wants to beg, without the soul proposing expressly to Him what and how. Everything is included and implicit or concealed, and

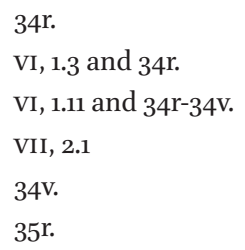


comprehended in that divine look and in conformity with the love of God. ${ }^{47}$

As is typical of the seventh mansion, Maria associated this prayer with a fresh affirmation of truth.

At the same time I was fully assured again that all those operations, illuminations and ways of praying of the spirit etc, which have been in me for two years in relation to the king of France, all occurred and have been produced in me by the divine spirit. For that truth I would have well wanted to sustain as many deaths as I have members in my body. ${ }^{48}$

The numerous parallels with the fourth to seventh mansions of The Interior Castle and the Latin manuscript about the Dutch War are really extraordinary. Not only are these higher levels of mental prayer represented in Maria's writings; she also takes over a series of literary motifs from The Interior Castle, such as the motif that it is God who wants the soul to write about her inner experiences, ${ }^{49}$ that the soul is like a second heaven for God, ${ }^{50}$ that everything has to be discerned time and again, ${ }^{51}$ and that there can be no doubt about these inner perceptions. ${ }^{52}$ Maria even explicitly referred to The Interior Castle to indicate that she felt like Teresa about her intimate friendship with the divine majesty who granted her the richness of her inner life:

This sweet majesty I see and carry constantly within me either in prayer or elsewhere. Nothing can prevent me from perceiving him: that I constantly contemplate him and lovingly cling to him and speak and talk to him confidentially and as between friends, for the spirit that is unbound and free from everything and from all other things can reside in the interior castle of the soul: as if he is separated from other things that are manifold corporeal and sensual things. 53

All these parallels with The Interior Castle seem to be highly pertinent for a proper understanding of Maria's inner solidarity with the French king. In other

\begin{tabular}{ll}
\hline 47 & $35^{\mathrm{V} .}$ \\
48 & $35^{\mathrm{r}-35 \mathrm{~V} .}$ \\
49 & I, 1.1; I, 27; 3or. \\
50 & VII, 1.3; 31 v. \\
$5^{1}$ & IV, 1.4; VI, 2.6; VI, 3.4; 32V. \\
$5^{2}$ & V, 1.9; VI, 3.12; 31r; 33V; 35r. \\
53 & $30 \mathrm{~V}$.
\end{tabular}


words: Maria's political engagement was authorized through the supernatural stages of mental prayer which she experienced. Naturally she sided with the Spanish king, as she said, "because by nature I am more inclined to help the king of Spain, so as to desire and demand the prosperity of his arms, because he is our king and he is Catholic.5 54 But in the war against Holland she had - in a supernatural way - to identify with the French king, whom she considered to operate by divine mandate.

\section{Evaluation of Maria's Visions and Experiences regarding the French King}

Maria's chronicles about the French king probably started in 1670, and became more extensive in 1672 at the beginning of the war against Holland. ${ }^{55} \mathrm{After}$ that she empathized intensely with his ups and downs during this war, because she believed that God himself had initiated her spiritual engagement with him. So time and again she saw herself alongside the French king, blessing him:

I perceived that the Beloved put me on the side of this king, and that the Beloved made me inclined towards him, as if I had to cooperate with that king. The blessing, which I on the Beloved's demand had given him in advance, I again bestowed on him and his army with powerful and vibrant love. ${ }^{56}$

Often she inwardly saw the French king as the child of God and her own child. She even saw all the French soldiers as her children, in need of her prayers to strengthen and animate them.

I have seen and understood that the king is loved by Jesus and by the same love he is also loved by me ... like a child whom Jesus loves. So when I pray for him, I say to Jesus: "My Beloved, help your child and mine, with your strength, wisdom and love." And from there results a further love which flows to all his subordinates and soldiers, as if all of them were my children. ${ }^{57}$

\footnotetext{
$5430 v$.

55 This is the earliest date that can be found in the Latin manuscript about the Dutch war. See $38 v$.

563 or. See also 35 r, 39r, 47v, etc.

$5730 v$.
} 
By considering political affairs while absorbed in mental prayer Maria clearly showed that for her divine love is not restricted to inner feelings but may have outward consequences. But what consequences could a contemplative woman living in strict seclusion evoke? Maria thought that her prayer might have consequences for nothing less than the outcome of the French king's war against Holland. In this sense her prayer could be seen as a political act.

Maria's primary political objective was the conversion of heretics and the reunification of the Church. She thought that this could be accomplished through the military intervention of the French king. In accordance with her political objective, her evaluation of the political situation and her divine inspiration Maria saw an outward key role for the French king in this battle and an inward key role for herself (and some of her companions).

Clearly I understood that God wanted to grant him [the king of France] those graces and provide him the divine help and by such prayer and not otherwise cooperate with the intention of the king and that God for this purpose took and chose some small and humble and at the same time pure and sincerely God-loving women, to pray for them, and among these few His Majesty seemed to want to use me unworthy as I am. ${ }^{58}$

Although the French king was criticized by many people in Maria's environment because of some of his political and strategic actions which seemed to jeopardize church unity, Maria stuck by him..$^{59}$ Neither could her natural solidarity with the Spanish king and the demands of her superiors to pray for him lure her away from the French camp. ${ }^{60}$ Maria was sure that it was God's will that she should sympathize with Louis XIV. She felt that God wanted her to express her love for this king and to make it effective through prayer. She did not even renounce the French king because of his moral shortcomings. ${ }^{61}$ Rather she was ready to suffer vicariously for him and herself endure divine punishment for his sins.

Why did Maria adopt this attitude? In the midst of all dilemmas Maria anticipated that church unity could be accomplished only through the victory of the French king. It was her longing for the reunification of the church that inspired her to side with the French king as the strongest party in this war. However, Maria must have felt some ambiguity about the French king, whose

$\begin{array}{ll}5^{8} & 41 r . \\ 59 & 3 \text { or, 3ov, 43r, 43v. } \\ 6 \text { o } & 31 r, 32 r, 34 v, 43 v \text { etc. } \\ 61 & 34 r .\end{array}$


ambitions did not readily coincide with her longings. At times she dissociated herself from the war, but nevertheless she remained trustful that God would ultimately give the divine blessing independently of the course of the battles. Eventually Maria understood that it was enough to persevere in loving God and all her fellows - Catholic or otherwise - and that everything else should be left to God. ${ }^{62}$

I gave place to the spirit of love, it began to operate very ingeniously, industriously and lovingly in such a sweetly flowing way, as if I was possessed inside and outside by a divine influence. All that was inside me cooperated with this love. All powers of the soul, heart and mind, were sort of dissolved, were opened and brought to freedom, in a way that I cannot explain. ${ }^{63}$

Finally Maria's real objective was to realize the divine goodness, kindness, compassion and love for all people. She was not exhilarated by a feeling of conquest. Rather she was seeking to incorporate everybody into the holy community of the church.

Elisabeth Hense TO.Carm, Ph.D (2001), Radboud University Nijmegen (The Netherlands), is Assistant Professor of Spirituality at that university. She has published and edited many monographs, translations and articles on spirituality, including Present-Day Spiritualities - Contrasts and Overlaps (Brill, 2014). E.Hense@ftr.ru.nl

\section{Bibliography}

Deblaere, A. 1962. De mystieke schrijfster Maria Petyt. Gent: Koninklijke Vlaamse Academie voor Taal- en Letterkunde.

Kavanaugh, K. \& Rodriguez, O. 1980. The Collected Works of St. Teresa of Avila. Washington: Washington Institute of Carmelite Studies.

Merlier, J.R.A. ed. 1976. Het Leven van Maria Petyt (1623-1677). Zutphen: Thieme \& Cie. Petyt, Maria. 1683/1684. Het leven vande weerdighe moeder Maria a S.ta Teresia, (alias)

Petyt, vanden derden reghel vande Orden der Broederen van Onse L. Vrouwe des berghs Carmeli, tot Mechelen overleden den 1. November 1677. 4 tt. in 2 voll. Ghent: gedruckt bij de hoirs van Jan vanden Kerchove. (Vilvoorde photogr. reprinted [2002]).

$62 \quad 44 \mathrm{r}$ and $44 \mathrm{v}$.

$6344 \mathrm{v}$. 